\title{
Assessment of the Bacteriological Quality of Three Recreational Water Centres in Port Harcourt, Rivers State, Nigeria
}

\author{
Austin A. Okwelle* and Nwaokugha-Douglas, Augusta \\ Department of Biological Sciences (Microbiology Unit) \\ Faculty of Natural Applied Sciences, Ignatius Ajuru University of Education \\ Rumuolumeni, P. M. B 5047, Port Harcourt, Rivers State, Nigeria \\ *Corresponding author
}

\begin{abstract}
A B S T R A C T
Due to the increasing risks of health problems arising from the use of swimming pools, the sustenance of regular monitoring has become imperative to ensure compliance to approved water quality standards and safety of the swimmers. The bacteriological qualities of three recreation water centers: Uniport swimming pool, Helena hotel swimming pool and Habitat hotel swimming pool in Port Harcourt, Rivers State was assessed. Water samples were collected from different zones in each of three swimming pools at a depth of $30 \mathrm{~cm}$ into $200 \mathrm{ml}$ sterilized wide plastic containers. Nutrient agar, MacConkey agar, Eosin-methylene blue agar and MacConkey broth were used to isolate and enumerate total aerobic heterotrophic bacteria, total and faecal coliforms (E. coli) respectively. The result showed that the Uniport swimming pool had the highest bacterial count of $5.0 \times 10^{3} \mathrm{cfu} / \mathrm{ml}$ with a prevalence of $66.7 \%$, while in Habitat hotel and resort swimming pool total bacteria count was $3.5 \times 10^{3} \mathrm{cfu} / \mathrm{ml}$ with $33.3 \%$ prevalence rate. There was no growth of bacteria isolates in water samples from Helena Haven swimming pool. The bacterial isolates were identified as Micrococcus sp. (9.7\%), Klebsiella sp. (16.6\%), Staphylococcus aureus (25.8\%), and Staphylococcus epidemidis $(48.4 \%)$ for the two positive swimming pools. The two positive swimming pools had bacterial counts above the recommended bacteriological standards for pool water. Although, E.coli was not detected, it is still needful for all the authorities concerned to apply standard corrective measures in order to provide good quality water for the numerous users.
\end{abstract}

\section{Introduction}

All over the world, recreational activity represents a significant part of the sociocultural and economic life of the people and it comes in various shades. The type of recreational facility available in an area determines the form of recreation that the people can engage on. According to APHA, (2005), the swimming pools, whirl pools and naturally occurring marine and fresh waters constitutes recreation water. To enhance access and convenience to the use of recreation water, individuals and organizations construct swimming pools within their houses, hotels, schools, wildlife parks and in beaches etc.

Amala and Aleru (2016) noted that individuals or group of people may go to 
swim in the pools for recreational activities and sports or for rehabilitative purposes. The use of swimming pools and other recreational water bodies provide opportunities for relaxation and promotion of healthy living, though the waters still harbor some inherent health risks, regardless of the fact that better management and modern technologies for water treatment and quality monitoring (e.g. real-time protocols for detecting bacteria) have made such facilities safer (WHO, 2003). Due to advances in civilization and urbanization, man-made water recreational facilities are now on the increase, but with all the associated public health concerns (Barna and Kadar, 2012).Ensuring the maintenance of good hygiene standards to prevent the occurrence of water borne diseases is one of the most critical factors that need to be adopted in order to safeguard the pool water and the health of users (Shirin et al., 2015).The quality of swimming pool water can be maintained by regularly changing the used water and through the application of appropriate concentrations of recommended disinfectants such as chlorine. However, Joyce et al., (2017), stated that the achievement of the standards set to secure safe and clean pool waters is not always met by the owners and operators of the facility in many countries.

Recreational waters therefore become contaminated through the deposition of infected skin secretion, saliva, mucus, vomit, urine, nose, accidental release of faeces from users, airborne contamination, incoming water from unhygienic sources, and droppings of birds (Sule and Oyeyiola, 2010). Other sources of contamination include the washing from sunscreen lotions and creams applied in the body of swimmers, hair and dust from the immediate environment.

Incidentally, different genera of pathogenic and opportunistic microorganisms can gain entry into the pool water by direct or indirect human contamination. Amala and Aleru (2016) in their studies on four different swimming pools in Port Harcourt reported the isolation, identification and prevalence of Staphylococcus epidermidis 10 (25\%), Bacillus cereus 6 (16\%), Micrococcus spp. and Staphylococcus aureus 2 (5\%). Similarly, Onifade et al., (2019) also identified Escherichia coli (66.7\%), Enterococcus faecalis (23.8\%)and Pseudomonas aeruginosa $(9.5 \%)$, while analyzing the bacteriological quality of public swimming pools in selected hotels in Ado-Ekiti, Nigeria. These different organisms continue to grow and multiplys uch that their population increases to a density that could result in illnesses like cutaneous, gastrointestinal or respiratory tract diseases in the users (Santhini et al., 2018). The outbreak of waterborne infections in other countries have equally been traced to the contamination of swimming pools by microorganisms (Dziuban et al., (2006) and Schets et al., (2011). In a number of such instances, the risk of infection is normally linked to the contamination of water body with feacal matter discharged from the swimmers and droppings of flying birds (Papadopoulou, 2008).

Cases of infectious diseases caused by the accidental swallowing of swimming pool water that was contaminated with microorganisms have been reported by many research workers [, Wade et al., (2003).,CDC, (2004)., Craun, (2005)and Kiyohara et al., (2010)].According to the findings from these studies, the skin, eye, ear and gastrointestinal tract infections are the most prevalent diseases that are spread through use of recreational waters. Hence, monitoring the hygiene conditions of the swimming pools and other recreational waterbodies should become a regular scientific exercise. This is why this research focuses on the assessment 
of the bacteriological quality of some recreational water centers in Port Harcourt, Rivers State.

\section{Materials and Methods}

\section{The study area}

The locations used for the study are Habitat Hotel and Resort Swimming Pool, Ozuoba (latitude $4^{\circ} 53^{\prime} 39^{\prime \prime} \mathrm{N}$, longitude $6^{\circ} 54^{\prime} 55^{\prime \prime} \mathrm{E}$ ), University of Port Harcourt Swimming Pool (latitude $4^{\circ} 533^{\prime} 57^{\prime \prime} \mathrm{N}$, longitude $6^{\circ} 55^{\prime} 13^{\prime \prime} \mathrm{E}$ ), and Helena Haven Hotel Swimming Pool, Ozuoba (latitude $4^{\circ} 53^{\prime} 29^{\prime \prime} \mathrm{N}$, longitude $6^{\circ}$ 54'59" E). The three locations are all in ObioAkpor Local Government Area, Rivers State of Nigeria. The map of Rivers State with Obio/Akpor Local Government Area and the study locations are shown on Figure 1.

\section{Description of swimming pool}

The three swimming pools selected for this study are rectangular in shape with depth of 2.2-2.85 $\mathrm{m}$ and sizes ranging from $50-1500 \mathrm{~m}$.

\section{Collection of samples}

Water samples were collected with the consent of the managers. Each water sample was collected in the evening from a depth of about $25 \mathrm{~cm}$ into a plastic container of $200 \mathrm{ml}$ from different point of each swimming pool.

\section{Preparation of culture media}

Nutrient agar (NA), MacConkey agar and Eosin methylene blue Agar (EMB) media were used for culture and isolation of bacterial species. The culture media were prepared by weighing the dehydrated powders, reconstituting and sterilizing them in the autoclave at $121^{\circ} \mathrm{C}$ for 15 minutes according to the manufacturer's direction. When cooled to $45^{\circ} \mathrm{C}$, the media were poured onto sterilized petri-dish plates aseptically, allowed to set and stored in the refrigerator at $4^{\circ} \mathrm{C}$ for further use.

\section{Bacteriological analysis}

The total aerobic heterotrophic bacteria count (THBC), Total coliform count(TCC) and Escherichia coli count were done by the spread plate technique using Nutrient agar (NA), MacConkey agar and Eosin methylene blue Agar (EMB) media respectively. $0.1 \mathrm{ml}$ aliquot of $10^{3}$ and $10^{4}$ dilution of each sample was inoculated into the prepared petri dish plates, aseptically spread with sterilized bent glass rod and incubated in an inverted position aerobically at $37^{\circ} \mathrm{C}$ for 24 hours. The number of colonies ranging from30-300were counted after incubation and recorded as colony forming units (cfu).

\section{Identification of the bacterial isolates}

The bacteria isolates were identified using cultural and morphological characteristics, Gram's reaction and some biochemical tests including motility, catalase, oxidase, citrate, methyl red, and indole test. The identities of the organisms were established using the methods of Cowan and Steel (1985), Holt et al., (1994) and Chesseborough (2006).

\section{Results and Discussion}

The results of the bacteriological analysis of three recreational centers are presented in the tables and figures below. Out of the three swimming pools studied, two showed growth of bacterial species with no bacterial growth observed in the third swimming pool.

Swimming pools provide important recreation center for individual or group swimming, relaxation for tourists, training for the sports of swimming and other social activities. The bacterial quality of three recreational water 
centers in Port Harcourt [i.e. Uniport Swimming Pool (UPSP), Habitat Hotel and Resort Swimming Pool (HHSP) and Helena Haven Hotel Swimming Pool (HHHSP)] was investigated in this study. Bacteriological analysis of the water samples indicated the presence of bacteria from two of the recreational water. The colony count showed that the Uniport Swimming Pool (UPSP) had the highest total heterotrophic bacteria of 5.0 x $10^{3} \mathrm{cfu} / \mathrm{ml}$ while Habitat Hotel and Resort Swimming Pool (HHSP) followed with $3.5 \mathrm{x}$ $10^{3} \mathrm{cfu} / \mathrm{ml}$. Helena Haven Hotel Swimming Pool (HHHSP) had no bacterial growth, which could be as a result of treatment of the swimming pool before collection of the sample. Onifade et al., (2019) in their studies also reported that the total bacteria, coliform and Escherichia coli counts of pool water samples were higher after use than before use. The organisms identified are Staphylococcus epidermidis, Staphylococcus aureus, Klebsiella and Micrococcus species. However, the Escherichia coli bacteria was not identified in the two swimming pools with colony counts. Although, E. coli was isolated from the swimming pool water samples in this study other workers had isolated and identified $E$. coli as one of the major contaminant of recreation water (Saberianpour et al., (2015) and Yedeme et al., (2017). Comparison of occurrence of the identified bacteria species from the two swimming pools showed that Staphylococcus epidermidis had the highest occurrence of 15 colonies with the prevalence rate of $48.4 \%$, followed by Staphylococcus aureus, having 8 colonies with $25.8 \%$, Klebsiella sp 5 colonies (16.1\%) and Micrococcus species with 3 colonies and prevalence of $9.7 \%$. Individually, the University of Port Harcourt Swimming Pool (UPSP) alone had a total of 19 bacterial isolates making up 58.8\%, while that of the Habitat Hotel and Resort Swimming Pool (HHSP) was 12 isolates with
41.2\%. The Staphylococcus aureus and Klebsiella species are known pathogenic organisms, while the Staphylococcus epidermidis and Micrococcus species are usually regarded as opportunistic pathogens or commensals. Santhini et al., (2018) reported the isolation and identification of Staphylococcus aureus, Pseudomonas aeruginosa, P.fluorescens, Enterobacter cloacae and Klebsiella pneumoniae, while Ehrampoosh et al., (2011) and Bello, et al., (2012)identified E. coli, Actinobacteria, Pseudomonas alcaligenes, Pseudomonas aeruginosa and Klebsiella pneumonia in the bacteriological analysis of water samples from residential and commercial swimming pools in Lagos and Mumbai. Similarly, George et al., (2014) in the microbiological evaluation of swimming pool water samples in Ghana isolated and identified Staphylococcus epidermidis, Staphylococcus aereus, Klebsiella pneumoniae, Enterobacter faecalis and E. coli.

The high prevalence of different bacteria species recorded from the two swimming pools in this study is a revelation that either the source of raw water supplies to the pools may not have been adequately protected and a failure or compromise in the pool water treatment schedules.

This agrees with the findings of Borchardt et al., (1971) in the assessment of public water supplies. The minimum bacteriological specifications for swimming pools may vary from one country to another Edberg et al., (2000) stated that pool water samples should not contain any microorganism in $100 \mathrm{ml}$ of water. This is because some the swimmers may accidental swallow the water while swimming. Generally, the high total aerobic bacteria count was in excess of the WHO (2003) permissible limit for swimming water. 
Table.1 Characterization and identification of bacterial isolates from two Recreational Water

\begin{tabular}{|l|c|c|c|c|c|}
\hline Organisms & $\begin{array}{c}\text { Gram } \\
\text { Reaction }\end{array}$ & $\begin{array}{c}\text { Coagulase } \\
\text { Test }\end{array}$ & $\begin{array}{c}\text { Catalase } \\
\text { Test }\end{array}$ & $\begin{array}{c}\text { Citrate } \\
\text { Test }\end{array}$ & Motility \\
\hline Staphylococcus epidermidis & + & - & - & - & - \\
\hline Staphylococcus aureus & + & + & + & - & - \\
\hline Klebsiella sp. & - & - & + & - & + \\
\hline Micrococcus sp. & + & - & + & - & - \\
\hline
\end{tabular}

N/B+: =Positive -: = Negative

Table. 2 Comparison of bacterial isolates from the swimming pools

\begin{tabular}{|l|c|c|c|c|}
\hline \multicolumn{1}{|c|}{ Organism } & UPSP & HHRSP & Total No. & Percentage (\%) \\
\hline Staphylococcus epidermidis & 9 & 6 & 15 & 48.4 \\
\hline Staphylococcus aureus & 4 & 4 & 8 & 25.8 \\
\hline Klebsiella sp & 3 & 2 & 5 & 16.6 \\
\hline Micrococcus sp & 3 & 0 & 3 & 9.7 \\
\hline Total $(\mathbf{\%})$ & $\mathbf{1 9}(\mathbf{5 8 . 8 )}$ & $\mathbf{1 2 ( 4 1 . 2 )}$ & $\mathbf{3 1}$ & $\mathbf{1 0 0}$ \\
\hline
\end{tabular}

N/BUPSP: Uniport Swimming Pool; HHRSP: Habitat Hotel Resort Swimming Pool

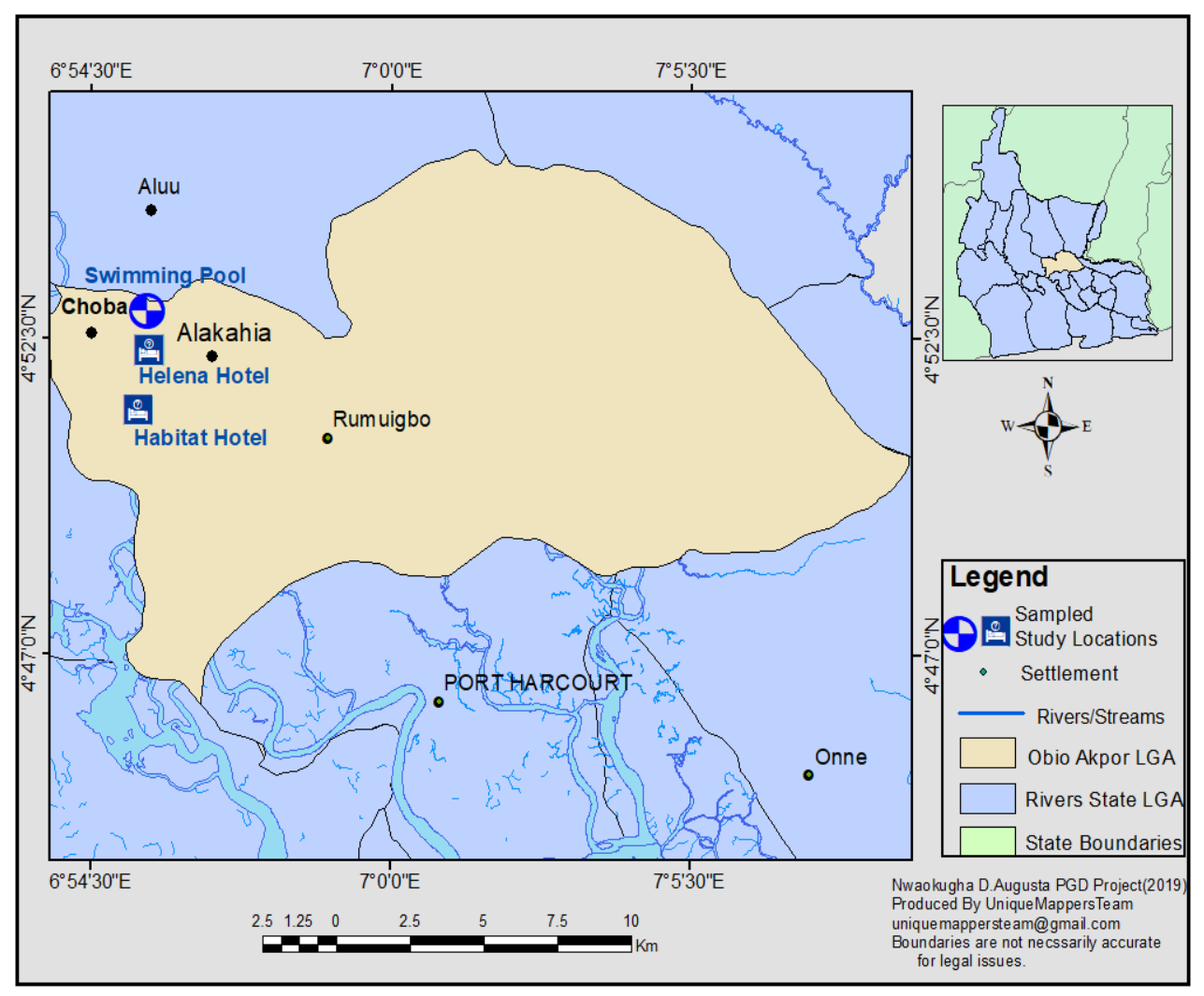

Fig.1 Map of Rivers State showing Obio/Akpor LGA and Locations of sample site 


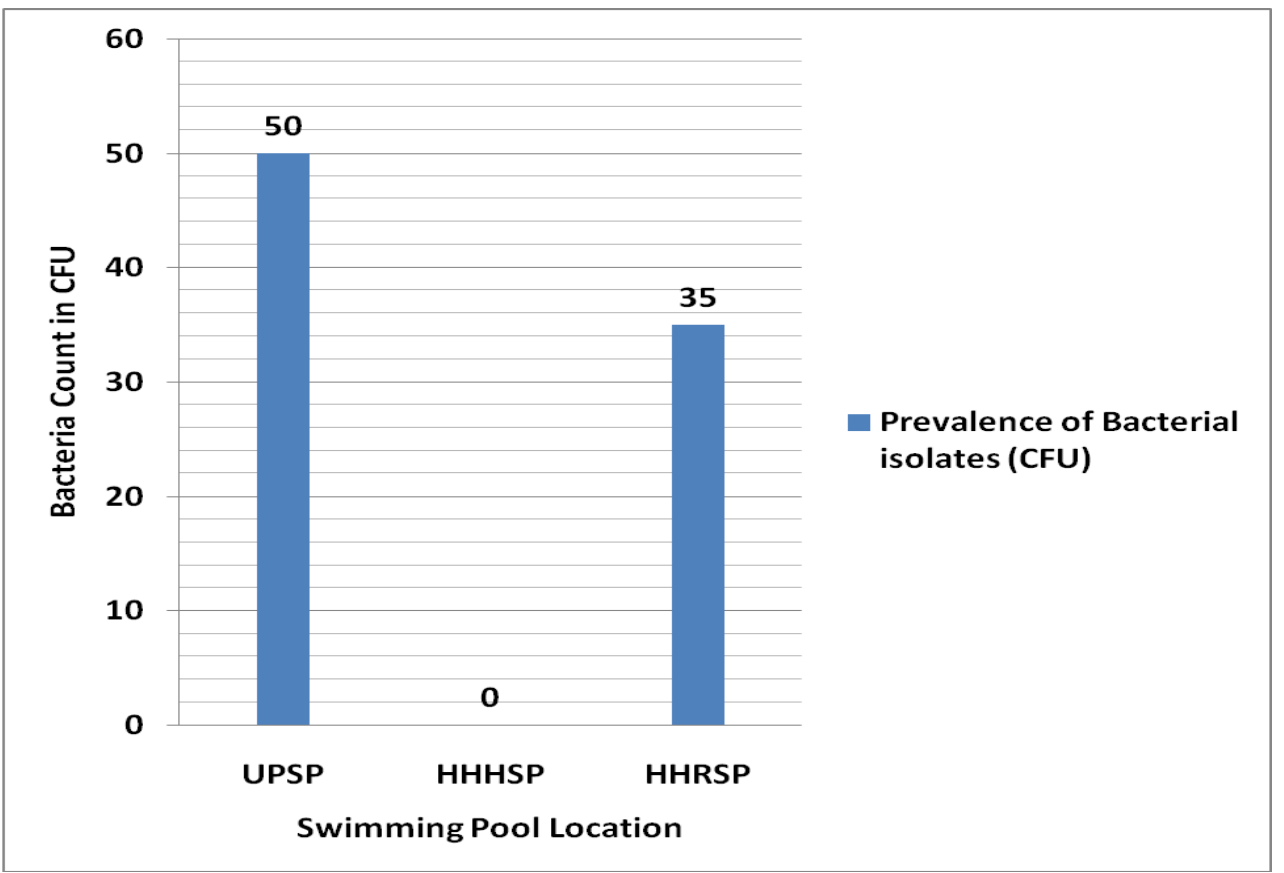

N/B:UPSP: University of Port Harcourt Swimming Pool HHHSP: Helena Haven Hotel Swimming Pool

HHRSP: Habitat Hotel and Resort Swimming Pool

Fig.2 Total bacterial count of the three swimming pools

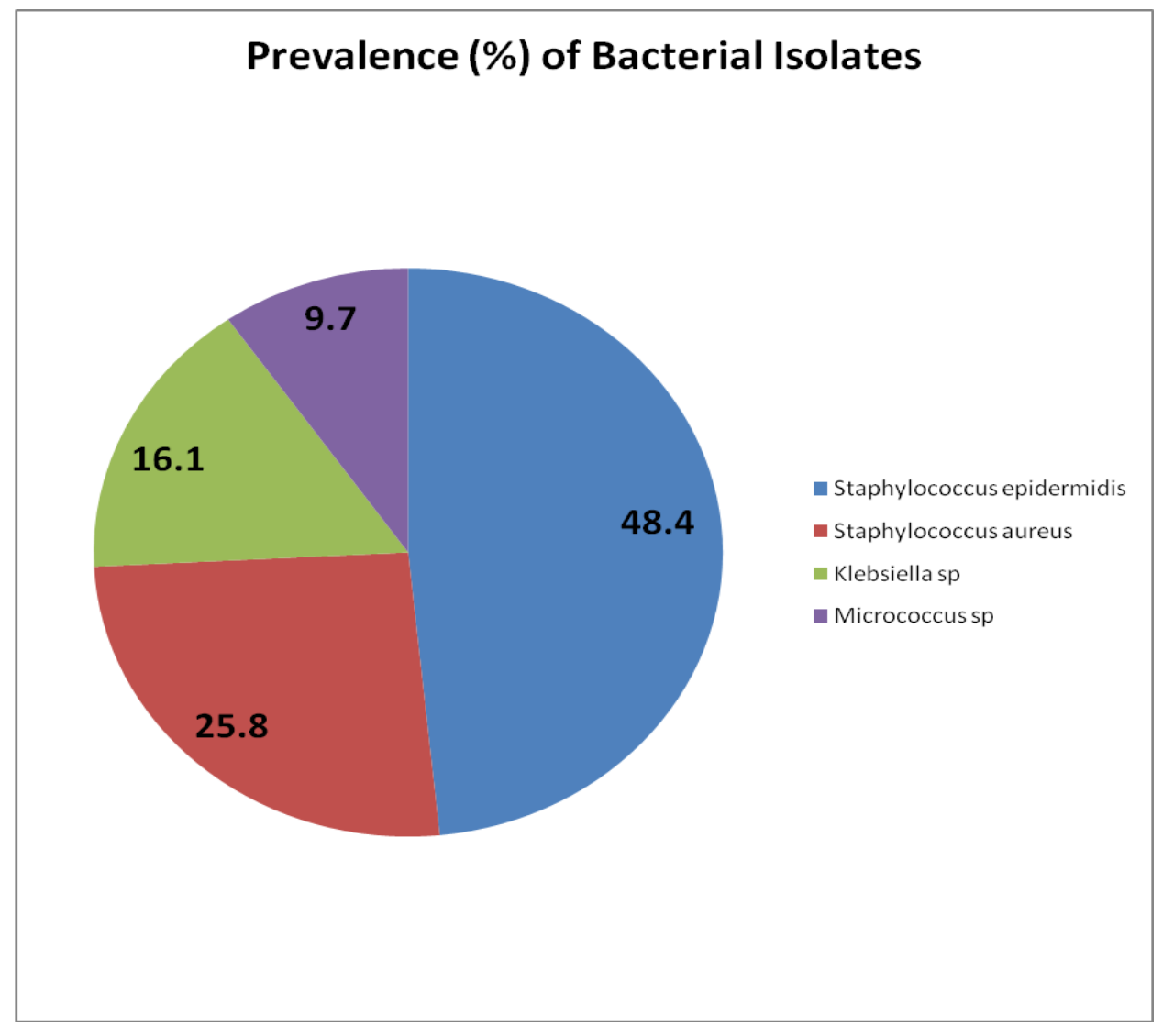


Fig.3 Prevalence of bacterial isolates from the swimming pools

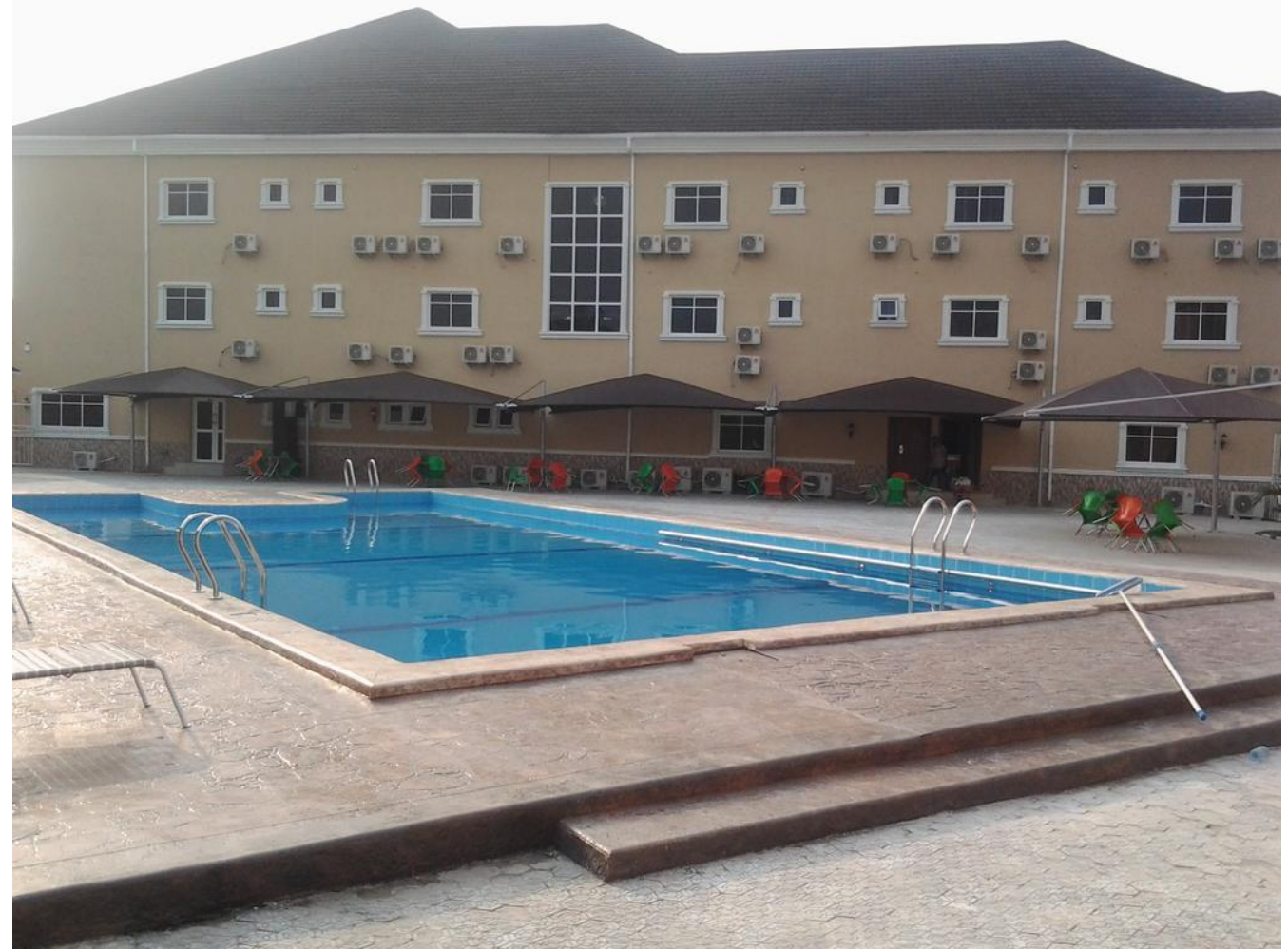

Plate.1 Habitat Hotel and Resort Swimming Pool

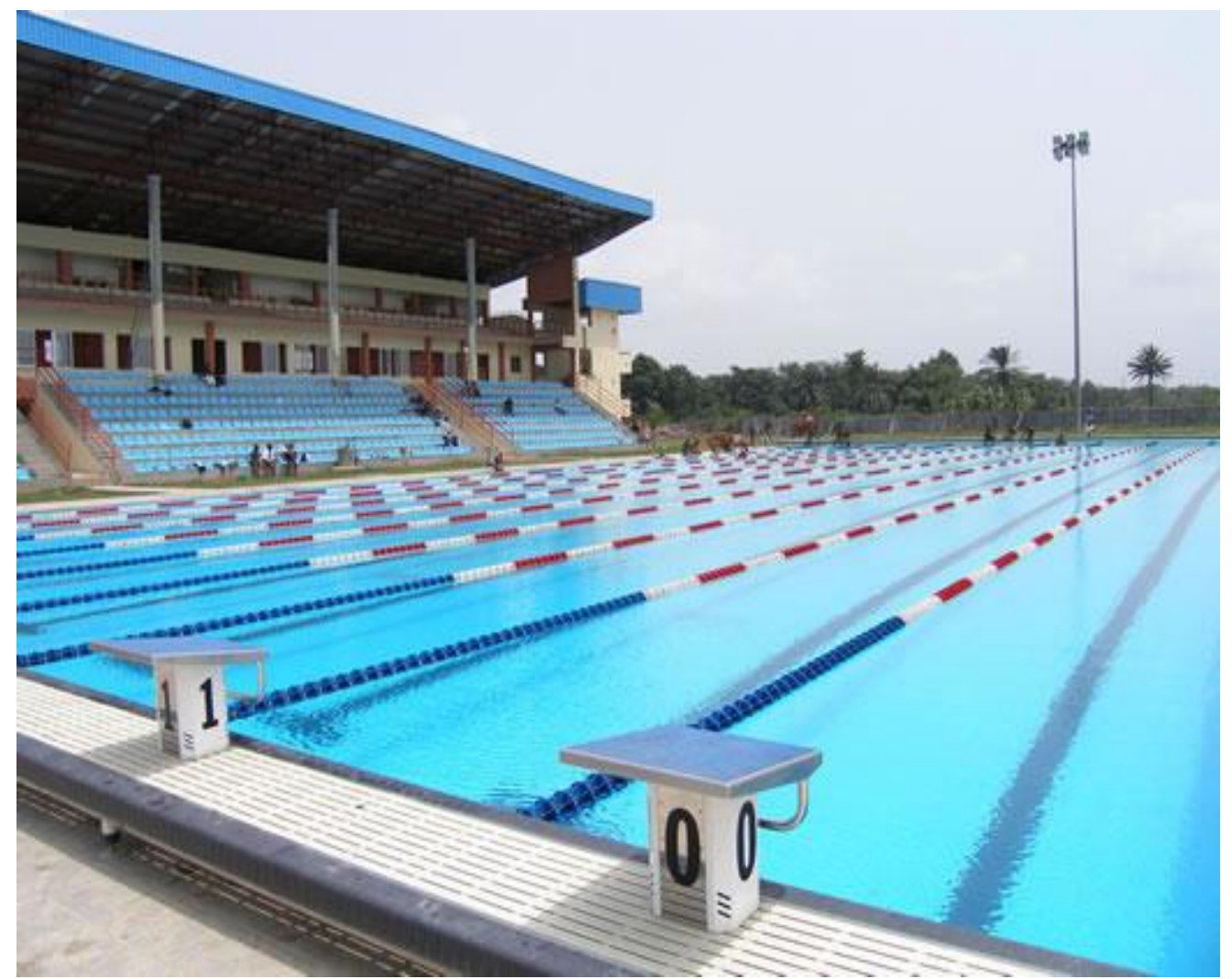

Plate.2 University of Port Harcourt Swimming Pool 


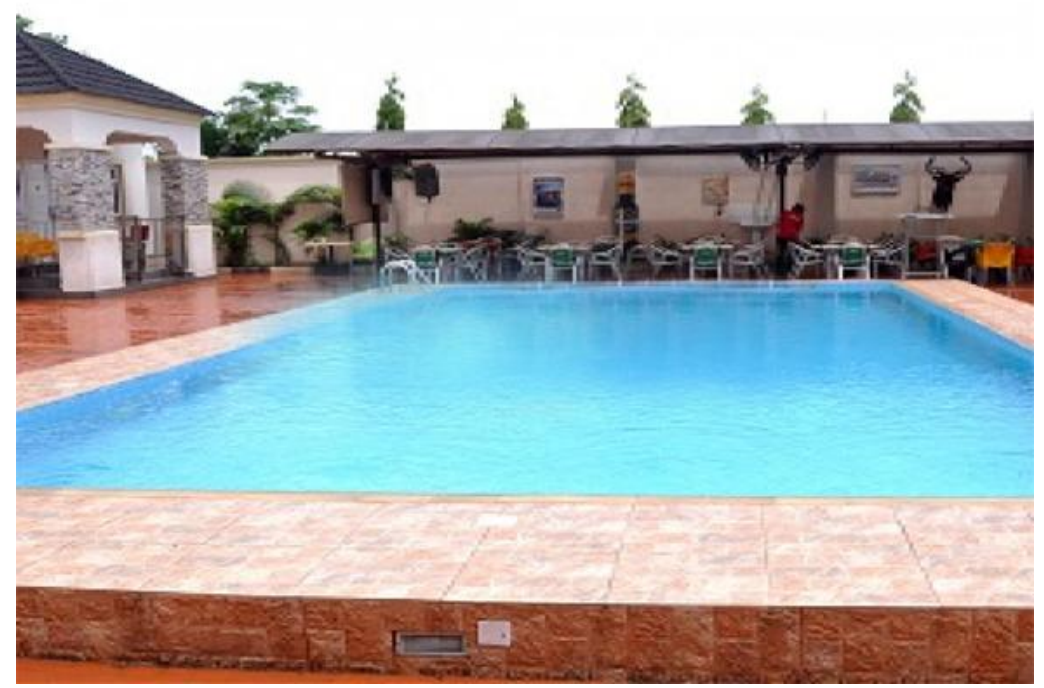

Plate.3 Helena Haven Hotel Swimming Pool

This could be an indication of deposition of high levels of organic matter, animal and human wastes, which are the main sources of microorganisms in water. According to Howe et al., (2002) other sources of bacterial contamination of water bodies includes surface runoff, discharges from septictanks, seepages from faulty sewage treatment facilities and the natural soil.

Based on the result of this study, two of the swimming pools investigated had bacterial counts in excess of the stipulated limits and so did not meet up with the bacteriological water quality standards required of a swimming pool. The owners and operators of the swimming pools should allow professionals to test the pool water regularly to ensure safety of the users and secure public confidence of the facility. The operators and swimmers need to be enlightened on water safety measures, personal hygiene and simple water treatment processes.

\section{References}

APHA (2005). Standard methods for the examination of water, $21^{\text {st }}$ edition. American public health association,
Washington, DC

Bello, O.O., Mabekoje, O.S., Egberongbe, H.O., and Bello, T.K. (2012). Microbial qualities of swimming pools in Lagos, Nigeria. International Journal of Applied Science and Technology. 2:89-96.

Borchardt, J.A, Walton, G. (1971). Water quality and treatment: A handbook of public water supply. American Water Works Association.1-52

Cambridge University Press, Cambridge, UK.pp158-195.

CDC, (2004). An outbreak of norovirus gastroenteritis at a swimming club Vermont. Morbidity and Mortality. Weekly Report, 53:793-795

Cheesebrough, M. (2006). District Laboratory Practice in Tropical Countries, Part II.

Cowan, A.W. and Steel, U.T. (1985).Manual for the Identification of Bacteria. Cambridge University Press, Cambridge.

Craun, G.F., Calderon, R.L. \& Crawn, M.F. (2005). Outbreaks associated with recreational water in the United States. Int. J. Environ. Health Res.15(4):243-262.

Dziuban, E.J., Liang, J.L., Craun, G.F., Hill, V., Yu, P.A., Painter, J., Moore, M.R, Calderon, R.L., Roy, S.L, \& Beach, M.J. (2006).Surveillance for waterborne disease and outbreaks associated with recreational water - United States, 2003- 
2004. MMWR.55:1-24

Edberg, S.C., Rice, E.W., Karlin, R.J. \& Aden, M.J. (2000). Escherichia coli: Thebest biological drinking water indicator. Public Health Protection Journal of Applied Microbiology. 88:106-11

Ehrampoosh, M.H., Jafari, A.A., Rahimi, S., Ghaneian, M.T., \& Khabiri, F. (2011). Study of Dermatophytic Fungal Species in Covered Swimming Pools in Yazd, Iran. Health System Research.7: 373 - 380.

George, O., Simon, K.S., Emmanuel, L. \& Emmanuel, T. (2014). Bacteriological quality assessment of swimming pools in OsuLabadi Area, Accra. Journal of Natural Science Research.4:126-129.

Greece: Investigation of the antibiotic resistance of the bacterial isolates. Int. J. Hyg. Environ. Health.211:385-397.

Holt, J.G., Krieg, N.R., Seath, P.H.A., Satley, J.T., \&Williams, S.T. (1994). Bergey's manual of determinative bacteriology. $9^{\text {th }}$ Edition, Williams and Wilkins, Baltimore, 804.

Howe, A.D., Forster, S., Morton, S., Marshall, R., Osborn, K.S., Wright, P. and Hunter, PR. (2002). Cryptosporidium oocysts in a water supply associated with a cryptosporidiosis outbreak. Emerg Infect Dis.4(6):619-624

Joyce, M.E., Nathan, L.M., Howard, O., Benigna, G.N., \& Celsus, S. (2017). Determination of Bacterial Quality of Water in Randomly Selected Swimming Pools in Kampala City, Uganda. Hindawi New Journal of Science. Article ID 1652598, 7 pages.

Onifade, O. E., Busayo, M. O.\& John, B. (2019). Assessment of the Physicochemical and Bacteriological Quality of Public Swimming Pool in Selected Hotels in AdoEkiti, Nigeria. South Asian Journal of Research in Microbiology, 4(3): 1-9.

Papadopoulou, C., Economou, V., Sakkas, H.,
Gousia, P., Giannakopoulos, X., Dontorou, C, \& Filiossis, G. (2008). Microbiological quality of indoor and outdoor swimming pools in

Saberianpour, S., Momtaz, H., Ghanbari, F., and Mahmodi, F. (2015). Assessment of bacterial and fungal contamination in public swimming pools in Shahrekord. Iran. J. Trop. Dis. 4(2):1-4

Santhini S. Nair, SupriyaKamble, P.D. Anthappan, Ambika S. Nair. (2018). Bacteriological assessment of swimming pools in residential and commercial sectors in mumbai. International Journal of Research and Analytical Reviews 5(3): 26a-33a.

Schets, F.M., Schijven, J.F. \& de Roda, H.M. (2011). Exposure assessment for swimmers in bathing waters and swimming pools. Water Research.45:2392-2400

Sule, I. O and Oyeyiola, G.P. (2010). Biological assessment of some swimming pools within Ilorin metropolis, Kwara of Nigeria. Bioresearch Bullentin.1:29-33.

Wade, T. J.,Pai. N., Eisenberg, J.N.S. and Colford, J.M. (2003). Environmental protection agency, water quality guidelines for recreational waters prevent gastrointestinal illness. A systematic review and meta-analysis environmental health perspective 111(B); 1102-1109

World Health Organization (2003). Guidelines for Safe Recreational Water ( $3^{\text {rd }}$ edition), 3:1120.

Yedeme, K., Legese, M.H., Gonfa, A, \&Girma, S. (2017). Assessment of physicochemical and microbiological quality of public swimming pools in Addis Ababa, Ethiopia. Open Microbiol J. 11:98-104.

\section{How to cite this article:}

Austin A. Okwelle and Nwaokugha-Douglas, Augusta. 2020. Assessment of the Bacteriological Quality of Three Recreational Water Centres in Port Harcourt, Rivers State, Nigeria. Int.J.Curr.Microbiol.App.Sci. 9(06): 4140-4148.

doi: https://doi.org/10.20546/ijcmas.2020.906.486 